\title{
Meningkatkan Kesadaran Masyarakat Mengenai Kerelawanan Tanggap Bencana Dan Protokol Kesehatan Dimasa Pandemi
}

\author{
Siti Hamidah ${ }^{1 *}$, Sri Hidayah ${ }^{2}$, Cindy Yuliastara ${ }^{3}$, Muhammad Dimas Januar ${ }^{4}$, Yustikarina \\ Agustiani $^{5}$, Nur Jannah ${ }^{6}$, Hatmawati ${ }^{7}$, Sellawati ${ }^{8}$ \\ 1,2 Universitas Lambung Mangkurat, Fakultas Ilmu Sosial dan Ilmu Politik, \\ Jl. H. Hassan Basry, Banjarmasin, Indonesia. \\ 3,4,5,6,7,8 Mahasiswa Program Studi Ilmu Pemerintahan, Universitas Lambung Mangkurat, Fakultas \\ Ilmu Sosial dan Ilmu Politik, \\ Jl. H. Hassan Basry, Banjarmasin, Indonesia, \\ *Email Korespondensi: sitihamidah.fisip@ulm.ac.id
}

Diajukan

29 Oktober 2021

\section{Informasi Artikel}

Diterima

20 November 2021
Diterbitkan

30 November 2021

\section{Keywords:}

Desa sungkai Tangguh

Kesadaran Masyarakat

Tanggap Bencana

Covid-19

Pengabdian masyarakat

\begin{abstract}
The flood disaster that hit Kabupaten Banjar in early 2021 maded these area got disaster alert status. The flood disaster struck and also coincided with the Covid-19 pandemic disaster made people affected by floods aware of the importance of disaster mitigation and also the importance of a village being prepared to face possible disasters. KKN-Tematik Fisip ULM which carries the theme "Village Tourism and Disasters Resilient Village" aims to develop villages according to the potential and problems they need to face. From this $K K N$-Tematik Fisip activities, it is hoped that it can build the village into a disaster-resilient village or village tourism. The socialization of disaster volunteerism in Sungkai Baru village is hoped that the community will understand the mechanism of volunteerism by cooperating with the Banjar Regency $B P B D$ as a speaker.
\end{abstract}

\begin{abstract}
ABSTRAK
Bencana banjir yang melanda Kabupaten Banjar awal tahun 2021 menjadikan daerah tersebut sempat berstatus siaga bencana. Bencana banjir yang melanda dan juga berbarengan bencana pandemi Covid-19 membuat masyarakat terdampak banjir menjadi sadar akan pentingnya mitigasi kebencanaan dan juga pentingnya sebuah desa siap menghadapi kemungkinan bencana. KKNTematik Fisip ULM yang mengusung tema "Desa Wisata dan Tangguh Bencana" bertujuan untuk membangun desa sesuai dengan potensi dan masalah yang dihadapi. Dari kegiatan KKN Tematik ini maka diharapkan dapat membangun desa menjadi desa tangguh bencana atau desa wisata. Sosialisasi kerelawanan bencana di desa Sungkai Baru diharapkan masyarakat memahami mekanisme kerelawanan dengan menggandeng BPBD Kabupaten Banjar sebagai pemateri.
\end{abstract}

\section{Copyright and License:}

Authors retain copyright and grant the journal right of first publication with the work simultaneously licensed under a Creative Commons Attribution 4.0 International License that allows others to share the work with an acknowledgment of the work's authorship and initial publication in this journal.

Journal homepage: https://ojs.wiindonesia.com/index.php/jecsr 


\section{PENDAHULUAN}

Kuliah Kerja Nyata (KKN) merupakan salah satu mata kuliah dengan tujuan utama memberikan pengabdian dan pemberdayaan masyarakat kepada mahasiswa. Pengalaman berpartisipasi dalam peran dimasyarakat melalui KKN akan bermanfaat bagi mahasiswa dan masyarakat itu sendiri. Proses KKN memiliki sifat khusus yang memadukan teori dengan praktek, sehingga membutuhkan landasan ideal yang secara filosofis memberikan gambaran dan pemahaman yang utuh tentang apa, bagaimana dan mengapa KKN dilaksanakan.

Sebagai salah satu perguruan tinggi, Universitas Lambung Mangkurat memiliki visi untuk menghasilkan lulusan yang unggul, mandiri dan berbudaya. Untuk itu diperlukan kegiatan yang dapat meningkatkan keterampilan mahasiswa melalui pengetahuannya. Dalam pelaksanaannya, mahasiswa diberikan pengetahuan untuk hidup di luar kampus di tengah-tengah masyarakat, untuk mengenali secara langsung terhadap permasalahan yang dihadapi masyarakat, guna meningkatkan pemahaman dan kemampuan mahasiswa serta untuk mendapatkan nilai tambah yang lebih besar pada pendidikan tinggi.

Desa Sungkai Baru merupakan salah satu desa yang berada di Kecamatan Simpang Empat, Kabupaten Banjar, Provinsi Kalimantan Selatan. Di sebelah utara berbatasan langsung dengan Desa Tungkap, Kecamatan Binuang, Kabupaten Tapin. Sungkai Baru terletak $82 \mathrm{~km}$ sebelah utara kota Banjarmasin. Meski di Desa Sungkai Baru memiliki tambang batu bara dan tambang batu gunung serta didominasi perbukitan, namun desa ini termasuk desa yang jarang atau bahkan tidak pernah terdampak bencana alam, baik itu banjir maupun longsor (Hasil wawancara dengan tokoh desa). Hal ini menjadikan masyarakat desa cenderung menjadi sukarelawan dan membantu daerah lain yang terkena bencana. Namun, pengetahuan tentang sistem kerja dan prosedur relawan masih tergolong minim.

Kemudian saat ini, masyarakat sedang menghadapi wabah virus Covid-19 yang sangat spesifik namun mempunyai kompleksitas yang tinggi, sehingga dianjurkan physical distancing, memakai masker sebagai salah satu upaya untuk mencegah penularan Covid-19. Dengan demikian KKN yang semestinya memberikan ruangan yang cukup bagi mahasiswa untuk berinteraksi secara langsung dan belajar bersama masyarakat dalam mengalami permasalahan tersebut.

\section{METODE}

Sebelum melakukan program Kuliah Kerja Nyata terdapat pra pelaksanaan kegiatan. Tahapan kegiatan dalam pra pelaksanaan Kuliah Kerja Nyata dibagi menjadi tiga tahapan yakni: observasi, penyusunan rencana program, dan sosialisasi program.

Observasi merupakan langkah awal yang dilakukan untuk mendukung terlaksananya semua program. Tujuannya adalah untuk mengetahui situasi dan kondisi masyarakat dilokasi Kuliah Kerja Nyata. Observasi tersebut meliputi pengamatan tentang kehidupan masyarakat, mata pencaharian, tingkat pendidikan, sarana dan prasarana desa, keadaan sosial, keagamaan, ekonomi, dan budaya masyarakat tersebut. Observasi yang dilakukan yaitu dengan melakukan pengamatan dan wawancara secara langsung dengan seluruh element yang ada di desa ini, baik itu perangkat desa (Kepala desa, Ketua RW, dan Ketua RT), tokoh masyarakat, tokoh kepemudaan sampai kepada masyarakat biasa.

Dari hasil observasi, kami melakukan pendekatan di wilayah Desa Sungkai Baru dan akhirnya menemukan beberapa masalah yang berhubungan dengan tema KKN kali ini. Permasalahan pertama iyalah Desa Sungkai Baru adalah wilayah desa yang relatif aman dari bencana alam, atau bisa dikatakan minim terjadi bencana alam. Bahkan pada saat banjir besar yang melanda Kabupaten Banjar kemarin Desa Sungkai Baru tidak sama sekali terdampak bahkan menjadi relawan untuk membantu desa-desa tetangga yang terdampak banjir. Selain itu diketahui kurangnya pengetahuan warga tentang kerelawanan yang baik dalam menangani bencana yang melanda. Selain itu kesadaran masyarakat untuk menggunakan masker bisa dibilang masih rendah terutama anak-anak yang tiap hari bermain di desa.

Berdasarkan informasi yang telah didapat dari observasi, kami mengajukan beberapa program yang nantinya diharapkan dapat membantu masyarakat dalam mengatasi beberapa persoalan yang ada di Desa Sungkai Baru. Adapun rencana program yang diajukan sebagai berikut: 
1. Sosialisasi Kerelawanan tanggap Bencana

2. Pembagian Masker dan Penyuluhan Protokol Covid-19

Setelah observasi dan koordinasi dirasa cukup maka kami mulai merencakana dan mematangkan konsep kegiatan serta melakukan koordinasi dengan pihak desa untuk acara yang bersifat mengumpulkan warga.

\section{SOSIALISASI KERELAWANAN TANGGAP BENCANA}

Desa Sungkai baru dapat dikatakan jarang terjadi bencana alam dan termasuk daerah dengan resiko bencana alam relatif rendah. Hal tersebut menjadikan desa Sungkai Baru lebih peka. Meskipun Desa Sungkai Baru tidak termasuk kawasan rawan banjir, tetap saja berbagai bentuk bencana harus diantisipasi. Bencana bisa terjadi kapan saja dan dimana saja, lebih-lebih lagi Negara Indonesia yang memang terkenal rawan akan bencana. Maka dari itu praktik penanganan tanggap bencana dirasa sangat perlu untuk seluruh kalangan masyarakat di Desa Sungkai Baru, khususnya masyarakat yang pernah menjadi relawan di bencana banjir besar yang melanda Kabupaten Banjar pada tahun 2019.

Tujuan dari adanya program ini yaitu agar seluruh masyarakat Desa Sungkai Baru dapat memahami dan mempraktikkan pemaparan dari program Sosialisasi Tanggap Bencana untuk menghadapi segala bentuk bencana yang mungkin saja bisa melanda disekitar mereka sebagai bentuk pertolongan pertama dengan baik dan sesuai prosedur keselamatan. Serta nantinya akan diberikan edukasi seputar Tanggap Bencana sesuai dengan pengalaman dan pemahaman dari tenaga ahli maupun pengalaman mahasiswa di bangku perkuliahan.

Manfaat dari adanya kegiatan ini yaitu dapat memberikan pemahaman kepada seluruh masyarakat Desa Sungkai Baru untuk membentuk mereka sebagai warga yang tanggap dalam menanggapi segala bentuk bencana baik yang akan datang secara langsung maupun tidak langsung. Selain itu agar masyarakat paham apa saja penyebab terjadinya bencana, apa tanda-tanda sebelum terjadinya bencana serta bagaimana pertolongan pertama maupun cara menanggulanginya agar bencana tersebut dapat dicegah dan tidak dapat terjadi lagi.

Sasaran dari program ini yaitu menyasar kepada masyarakat terkhusus warga yang sudah memiliki umur yang cukup, dan kemudian dapat menyalurkan ilmu sosisalisasi kepada seluruh masyarakat desa. Masyarakat yang berhadir dalam sosialisasi ini yaitu perwakilan setiap Rukun Tetangga di Desa Sungkai Baru seperti RT.01, RT.02 dan RT. 03.

\begin{tabular}{|l|l|l|l|}
\hline No & Tanggal & Waktu & Keterangan \\
\hline 1 & $05 / 09 / 2021$ & $09.30-10.00$ & Persiapan kegiatan Sosialisasi Tanggap Bencana \\
\hline 2 & $05 / 09 / 2021$ & $10.00-13.30$ & $\begin{array}{l}\text { Monitoring dan pelaksanaan kegiatan Sosialisasi Tanggap } \\
\text { Bencana }\end{array}$ \\
\hline 3 & $05 / 09 / 2021$ & $13.30-13.40$ & Penutupan kegiatan Sosialisasi Tanggap Bencana \\
\hline 4 & $05 / 09 / 2021$ & $13.40-13.55$ & $\begin{array}{l}\text { Sesi foto bersama perwakilan BNPB, Mahasiswa, Dosen } \\
\text { Pembimbing Lapangan, Kepala Desa serta peserta } \\
\text { sosialisasi. }\end{array}$ \\
\hline
\end{tabular}

Untuk langkah awal pelaksanaan program Sosialisasi Tanggap Bencana ini yaitu seluruh mahasiswa kelompok 15 terjun langsung ke lapangan, bersamaan dengan hadirnya Dosen Pembimbing Lapangan dan anggota BNPB Kabupaten Banjar. Kami melakukan persiapan sosialisasi di tempat yang telah disediakan, yang bertempat di Taman Kanak-Kanak Tunas Muda Desa Sungkai Baru. Persiapan dimulai dari pemasangan sound system set, proyektor, banner, konsumsi, meja, karpet dan perlengkapan lainnya. Selanjutnya kami mengajak perwakilan warga dari RT.01, RT.02 dan RT.03 dan Kepala Desa beserta jajarannya. Sebelum memulai pelaksanaan kegiatan, yang perlu dilakukan oleh mahasiswa yaitu menghubungi anggota BNPB untuk persiapan memberikan materi dari sumber yang terpercaya untuk program ini. Materi tersebut kemudian dipaparkan oleh salah satu anggota BNPB dalam bentuk power point. Setelah pemaparan materi selesai, kami mengadakan sesi tanya jawab serta diskusi bersama. Mulai dari pengertian bencana, apa saja bentuk bencana, bagaimana cara terbaik untuk menanggapi bencana, bagaimana menjadi relawan yang baik, 
tanda-tanda adanya bencana, asal-usul terjadinya bencana dan sebagainya. Materi ini merupakan materi pengantar bagi masyarakat pemula yang akan terjun sebagai relawan bencana, mengingat Desa Sungkai Baru pernah menjadi relawan darurat saat terjadi bencana besar di Kalimantan Selatan kemarin. Adapun tahapantahapan yang kami lakukan pada program ini yaitu:

1. Persiapan menghadirkan pemateri dari anggota BNPB Kabupaten Banjar, dan

2. Materi dan teknis terkait Sosialisasi Tanggap Bencana.

Dengan adanya edukasi program ini kami mahasiswa berharap masyarakat Desa Sungkai Baru dapat menjaga dan menyelamatkan diri mereka dari segala keadaan dengan sebaik mungkin, dan menghindari bencana apapun. Kami pun berharap dengan adanya sosialisasi yang kami berikan kepada masyarakat Desa Sungkai Baru dapat pengetahuan kepada mereka untuk mengenali indikator terjadinya bencana serta dapat menyelamatkan dirinya dan orang lain untuk mencari tempat berlindung.

\section{PEMBAGIAN MASKER DAN PENYULUHAN PROTOKOL COVID-19}

Saat ini dunia sedang dilanda wabah penyakit yang sangat besar, yaitu virus Covid-19. Virus ini telah menyebar ke seluruh belahan dunia, termasuk Indonesia. Hal ini membuat negara kita sempat menduduki posisi ke-3 se-Asia Tenggara dalam kasus positif Covid-19.

Berdasarkan informasi yang telah kami dapatkan bahwasannya Desa Sungkai Baru terkena paparan dan dampak dari pandemi Covid-19. Setelah adanya bencana yang melanda ini, membuat Desa Sungkai Baru juga merasakan dampak dari adanya virus tersebut. Meskipun angka kasus positif di Desa Sungkai Baru tergolong sedikit, kita tetap harus waspada dan sigap dalam mengurangi paparan virus ini. Pandemi Covid19 sangatlah merugikan masyarakat, termasuk kerugian ekonomi dan lain-lain. Seperti sepinya aktivitas jual beli di pasar, minimnya minat pembeli yang lebih memilih belanja online daripada membeli secara langsung, minimnya masyarakat yang beraktivitas, dan lain sebagainya. Maka dari itu pembagian masker dan penyuluhan protokol kesehatan kepada masyarakat Desa Sungkai Baru dirasa sangat perlu dilaksanakan, terkhusus kalangan anak-anak dan lansia yang sangat rentan terkena paparan virus Covid-19 ini.

Tujuan dari adanya program ini yaitu agar seluruh masyarakat Desa Sungkai Baru dapat memahami dan mempraktikkan apa yang telah disuluhkan kepada masyarakat mengenai bahayanya paparan virus Covid19 ini. Hal ini dilaksanakan untuk memberi pemahaman kepada masyarakat agar siap menghadapi bahaya pandemi dan mengetahui bagaimana cara yang tepat untuk menanganinya. Serta nantinya akan diberikan edukasi mengenai penggunaan protokol kesehatan yang baik dan benar sesuai pengalaman mahasiswa di bangku perkuliahan maupun diluar perkuliahan.

Manfaat dari adanya program ini yaitu dapat memberikan pemahaman kepada seluruh masyarakat Desa Sungkai Baru mengenai pentingnya penerapan protokol kesehatan di kehidupan sehari-hari. Selain itu mahasiswa juga memberikan beberapa protokol kesehatan seperti masker dewasa, masker anak beserta handsanitizer agar dapat digunakan sebagaimana mestinya.

Sasaran dari program ini yaitu menyasar kepada masyarakat terkhusus warga yang kurang tanggap dalam mengurangi penyebaran virus Covid-19 dan masyarakat yang masih minim pengetahuan tentang bahaya virus ini seperti lansia dan anak-anak di RT. 01, RT.02 dan RT.03.

Untuk langkah awal pelaksanaan program pembagian masker dan penyuluhan protokol kesehatan ini yaitu seluruh mahasiswa Kelompok 15 terjun langsung ke lapangan. Mahasiswa berkeliling desa untuk mengumpulkan beberapa masyarakat seperti anak-anak. Kemudian masyarakat dikumpulkan di satu tempat, seperti taman kanak-kanak. Persiapan dimulai dari penggadaan lokasi titik kumpul, penyusunan posisi duduk berjarak, persiapan pemateri dan perlengkapan lainnya. Selanjutnya mahasiswa berdiri di depan beberapa masyarakat untuk menyampaikan penyuluhan terkait pandemi Covid-19. Disana mahasiswa memberikan edukasi seputar pentingnya penggunaan protokol kesehatan untuk mencegah paparan positif Covid-19. Materi disampaikan oleh perwakilan mahasiswa yang telah dipelajari sebelumnya dalam bentuk dokumen di handphone. Materi penyuluhan yang dipaparkan terkait pengertian apa itu pandemi, bagaimana gejala untuk pasien yang terpapar Covid-19, bagaimana penanganan pertama setelah muncul gejala, dan lain-lain. Materi ini merupakan materi dasar bagi masyarakat untuk mengetahui sekilas mengenai virus Covid-19 agar

Journal Empowerment and Community Service Vol. 1, No. 01, November 2021 
masyarakat lebih berhati-hati dan tanggap dalam melawan penyebaran virus Covid-19. Setelah pemaparan penyuluhan selesai, kami mengadakan sesi diskusi dan tanya jawab kepada masyarakat, untuk masyarakat yang bisa menjawab akan diberikan masker dan handsanitizer gratis.

Adapun tahapan-tahapan yang kami lakukan pada program ini yaitu:

1. Persiapan penggunaan titik kumpul pembagian masker dan penyuluhan protokol kesehatan.

2. Menyediakan materi dan teknis terkait penyuluhan protokol kesehatan.

Dengan adanya penyuluhan ini kami mahasiswa berharap masyarakat Desa Sungkai Baru dapat menjaga dan melindungi diri mereka dari paparan virus Covid-19 dengan sebaik mungkin, dan menghindari segala bentuk penyakit dengan menerapkan protokol kesehatan pada kehidupan sehari-hari. Kami pun berharap penyuluhan ini dapat dipraktikkan dengan baik dan kiranya masyarakat dapat memahami gejalagejala jika terpapar virus Covid-19.

\section{KESIMPULAN DAN SARAN}

Dari beberapa program kerja yang telah terlaksana diatas, dapat disimpulkan bahwa Desa Sungkai Baru merupakan desa yang relatif aman dari bencana alam seperti banjir, tanah longsor, dan lain-lain. Kurangnya penerapan prokes dalam kehidupan sehari-hari juga menjadi hal yang perlu kita perhatikan. Kemudian pada program kerja pembuatan profil desa mendapatkan apresiasi dari sekretaris Desa Sungkai Baru karena berhasil menggali beberapa informasi terkait sejarah awal berdirinya Desa Sungkai Baru.

Secara garis besar berbagai program yang telah direncanakan sudah terlaksana dengan sebaik mungkin. Di sisi lain, program-program kerja yang telah dilaksanakan mendapat partisipasi dan sambutan baik dari masyarakat Desa Sungkai Baru. Hal ini dapat dilihat dari keikutsertaan masyarakat disana, baik dari aparat desa, orang tua, pemuda-pemudi, maupun anak-anak yang sangat antusias mengikuti pelaksanaan program kerja KKN dari Kelompok 15 Desa Sungkai Baru.

Saran kami untuk Desa Sungkai Baru yaitu agar kiranya desa ini lebih memfokuskan brading desa kearah tanggap bencana, meskipun wilayah desa ini relatif aman dari bahaya bencana. Terlepas dari saran diatas, Desa Sungkai Baru memiliki kemungkinan dalam mengembangkan potensi desa seperti dibidang peternakan dan perkebunan. Kemudian apabila perhatian masyarakat desa mengenai penerapan protokol kesehatan masih kurang, dapat dilakukan penyuluhan kembali mengenai pentingnya penerapan protokol kesehatan di masa pandemi ini.

\section{UCAPAN TERIMA KASIH}

Ucapan terima kasih disampaikan kepada FISIP Universitas Lambungkurat yang telah mendukung berlangsungnya kegiatan ini

\section{REFERENSI}

Kelompok 15. 2021. Laporan Kelompok KKN Tematik Fisip ULM desa Sungkai Baru. Laporan

Pemerintah Desa Sungkai Baru. 2021. Buku Profil desa Sungkai Baru Tahun 2020.

Wawancara dengan tokoh masyarakat. 27 Agustus 2021

Fadilah, Arif. Dkk. 2020. Meningkatkan Kesadaran Masyarakat Mengenai Tanggap Bencana dan Pengelolaan Lingkungan Hidup. Jurnal KKN. 